\title{
Obstacles of using Digital learning Platforms among University Students
}

\section{Prepared by}

Dr. Asmaa Gamal Abdelaih Abozeid

A Lecturer at Group Work Department, Faculty of Social Work - Assuit University

Dr. Ghada Abdelaall Ahmed Abdelaall

A Lecturer at Case Work Department, Faculty of Social Work - Assuit University 
مجلة كلية الخدمة الاجتماعية للدر اسات و البحوث الاجتماعية - جامعة الفيوك 


\section{Abstract:}

The study aims at recognizing the benefits and obstacles of using university platform "Microsoft Teams" through recognizing university students' attitudes and preparations toward using of digital platform and the aspects of students' benefits from the digital platform and the obstacles hindering university students from using the digital Platform "Microsoft Teams", and recommending suggestions to help students to overcome the obstacles of using Digital Platforms "Microsoft Teams" and getting benefits from this digital platform. The study is considered one of the analytical descriptive studies using the social survey approach on a sample of (300) student at Assuit University. The study revealed some obstacles hindering university students from using the digital Platform such as: the lack of infrastructure and the lack of financial capabilities to use the digital Platform.

\section{Key words:}

Obstacles, Digital learning Platforms, Students.

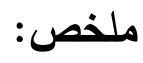

تهدف الدراسة إلى التعرف على معوقات استخدام واستفادة طلاب الجامعة من المنصة الرقمية "مايكروسوفت تميز"، وذلك من خلال التعرف على استعدادات واتجاهات طلاب الجامعة نحو استخدام المنصة الرقمية "مايكروسوفت تميز"، وكذلك التعرف على أوجه استفادة الطلاب من المنصة الرقية، والمعوقات التي تواجههم وتحول دون استخدامهم المنصة الرقمية مايكروسوفت تميز والاستفادة منها. ثم التوصل إلى أليات مقترحة في التعامل مع معوقات استخدام طلاب الجامعة للمنصة الرقمية "مايكروسوفت تميز". وتتتمي هذه الدراسة الي الدراسات الوصفية التحليلية، واستخدمت منهج المسح الاجتماعي على عينة قدرها (300) طالب موزعين على جميع كليات جامعة أسيوط النظرية والعملية، واستتجت الدراسة الي وجود عدة معوقات تحول دون استخدام الطلاب المنصة الرقمية "مايكروسوفت تميز" من أهمها عدم توفر بنية تحتية للاستخدام، وعدم وجود الإمكانيات المالية لاستخدام هذه المنصة. الكلمات المفتاحية: المعوقات، منصات التعليم الرقمي، الطلاب. 


\section{Firstly: Introduction to the study Problem:}

In the light of the current era where mobile devices and Electronic books are prevailing, users gradually tend to use digital platforms in learning acquisition. Although digital learning concept is not a new concept as it emerges during the nineteenth and at the beginning of the new century, it does not actually thrive until digital educational aids become more interactive and electronic devices become more available beside the easiness in use. Corona pandemic imposed new reality on education as countries of the world are exposed to great losses on all medical, social and educational levels leading to study suspension and closure of the universities to limit the spreading of the epidemic. The world is witnessing rapid developments in educational field as a result of the quantum leap of communication and information technology leading to the emergence of information technology. It is noted that there is a merger between information technology field and learning technology field leading to the emergence of educational ample new horizons represented in many technological inventions that are directly related to educational process including the digital learning (khyaia, 2019, P139).

The process of designing and presenting digital platforms through the internet is considered one of the most advanced uses of Internet in learning field as colleges and universities adopting the system of distance digital learning have approved the process of designing digital platforms and broadcasting them through the internet so as to enable the researcher to fellow and study the scientific content without attending lectures and meeting the professor face to face at lectures' rooms. Digital course is available during the whole day hours and holidays as students can access these courses at any time from everywhere, comment on the contents and opinions of others, get huge amount of information, and get access to course related sites at the same time of discussion (Salem, 2014, P15).

The University digital educational platforms aim at promoting students' independence in university life via reducing face -to -face teaching and increasing independence learning (Emmanuel, Paola, 2018, P.17).

Electronic platform launched by higher learning ministry is considered the first digital platform to offer educational services by setting mechanisms consistent with hybrid education system merging between traditional education and distance learning supposed to be executed in universities as of the academic year 2020/2021.

This platform represents a virtual learning environment enabling the easiness of communication among Faculty teaching members, students and different administrations as well as presenting scientific content in forms of educational videos, virtual classes' lectures, multi-specializations libraries and references, electronic exams saving time and effort exerted at traditional exams, easy way to 
register attendance and absence and fellow the educational process quality continuation(kaziz,2020.P3).

The platform enables faculty teaching members through Microsoft Teams Program to unify their communications and build cooperative study rooms contributing to forming educational environment distinguished by effectiveness and modernity for students and integrated with study schedule at every college. The platform provides an effective mechanism to check absence and attendance rates and number of educational teaching hours for every lecturer, and activates the accounts of "Office 365" for students and lecturers so as to get benefit from all applications and services offered by Microsoft Office in a state of preparedness for the new academic 2020/2021 AD for the sake of achieving the best results in a secured way. The university electronic platform offers electronic courses guaranteeing the easiness of communication between faculty teaching members and students and electronically providing information and services and expanding scientific content spread. Performance indicators Measurement enables a comprehensive vision for the performance of students and faculty teaching members and applying distance learning governance in addition to the integration with the rest of educational systems and this is confirmed by the study of Mohamed (2020) concluding the effectiveness of using interactive educational platforms in improving some teaching skills of the student and the teacher. Khyaia study (2018) has affirmed that digital platforms have great role in supporting and developing science learning of middle stage students. Mohamed's study (2019) has concentrated on developing production skills of middle stage students' digital education units through using electronic educational platform. Study of Hamid \& Yousef (2020) has affirmed the effectiveness of teaching methods through digital platforms in developing academic accomplishment motive among the female students of faculty of education in Jeddah university. Ismail's study (2019) has concentrated on measuring the impact of interaction between designing evaluation method and corrective feedback pattern through digital platforms and their impact in developing research self effectiveness and taking the vocational decision among higher studies' students and the results revealed the effectiveness of these methods through digital platforms. EL-Rabghy's study (2019) has concentrated on using open-ended resource electronic courses in vocational development of science female teachers in Jeddah City. Study of (Sousa \& Rocha, 2018) has concentrated on digital learning effectiveness through using open platforms for higher education's students and it concludes that there are benefits for the process of education and classroom lessons will improve academic results if these lessons are frequently offered using open platforms in an integrated method.

The study of (Oleg Ye, et.al, 2018) has tackled digital change role of higher education in Ukraine at the fourth industrial revolution age, and the study has 
concluded the need to develop digital change strategy of university education system in addition to reformation the effectiveness of information and communications as the change in university education system should include the update of company information technology. The study (Muhammad, et. Al, 2020) has recommended the necessity of turning traditional university education into education via using digital educational platforms because of its various merits. It also recommended the establishment of infrastructure supported by communications and information technology so as to meet the requirements of the current age as well as get benefit from technological developments in using digital platforms in university education.

The study (Badreya, 2015) has tackled the recognition of university students' trends concerning the use of social communication platforms in university education and it revealed the illiteracy of many students concerning dealing with modern technology. The study recommends the necessity of getting rid of technological illiteracy in advanced education. The study of (Vojtech \& Milan,2016) has affirmed the benefits of using digital platforms in university education for students but unfortunately the digital platforms needs high finance and intensive training for teachers and students.

The profession of social work is closely related to society as it enables its individuals to achieve the required change to keep up to the date due to its roles in many different fields whether the traditional or the advanced fields so as to improve the conditions of the society and to raise its level to the utmost level. The career of social service needs to update its learning methods and vocational practices via using technology especially digital education which helps university students to access the courses at any time and from everywhere and this is affirmed by the study of Mohammed(2020) concerning determining university students' trends of using digital platforms in university education in kingdom of Saudi Arabia and the study recommends the necessity of turning all university courses into open digital courses so as to be available to all society categories.

Abo Kheries Study (2020) aims at determining the requirements of using digital platforms in education as recognized by students and faculty teaching members and the study concluded some of the necessary requirements to use digital platforms in education including the spreading of electronic educational culture and the importance of using digital platforms in education and modern technologies by setting unified policy for universities concerning the use of these platforms.

Almisr study (2014) aims at recognizing female students ' trends concerning using electronic education in teaching social work. Saleh's study (2014) revealed the obstacles of using electronic education applications for social work students including: the lack of self-abilities of students, lack of time, inability to access 
internet and ineffectiveness of communications networks. The study of Ali (2016) aims at determining the range of students' readiness to electronic education and the study concluded that the students have the motive for electronic education.

Study of Mohammed (2012)aims at recognizing the points of view of faculty teaching members at the department of community work concerning the activation of electronic education in the light of global and local changes and the study recommends increasing the required finance for electronic education and providing required capabilities and places to practice electronic education inside the university as well as holding a workshop concerning the activation of electronic education.

Although the importance of using university digital platforms, there are a lot of obstacles hindering students during their use of electronic platform such as the lack of infrastructure for using digital platforms as affirmed by Ahmed's study (2000)that highlighted the most important challenges of digital education in Arab region through a foundation vision in a try to face these challenges. The study attributed these challenges to the lack of computers and technical problems concerning the internet...etc.

Study of Diab \&Brois (2019) aimed at detecting the obstacles of digital education in Algerian Schools and it concluded that digital education needs big budget to be applied and enough training for students and teachers.

Study of Safaa\& Sanaa(2019) aimed at identifying digital education obstacles among special education teachers and it recommended the necessity of increasing the awareness of teachers of using educational technologies through workshops and symposiums and providing teacher's training programs and increasing the awareness of students and their families of the importance of using digital education besides providing financial support.

Developing university education and inserting digital platforms is an important process but there are many obstacles hindering the use of university digital education platforms by university students consequently the current research enquiry will be determined through answering the following question: what are the obstacles of using university digital education platforms among university students?

\section{Secondly: The Study Questions:}

The current study tries to find out an answer for the following main enquiry: what are the obstacles hindering university students from using digital educational platforms? The following sub-enquiries are being derived from the main enquiry: 
What are the capabilities available for students to enable them to use digital platform "Microsoft Teams"?

What are the students' trends concerning using digital platform "Microsoft Teams"?

What are the aspects of benefit for university students from digital platform "Microsoft Teams"?

What are the obstacles hindering students from using digital platform "Microsoft Teams"?

What are the required suggestions to help university students to overcome the obstacles of using digital platform "Microsoft Teams"?

\section{Thirdly: The Study Aims:}

The current study aims at recognizing the obstacles of using digital educational platforms and this objective will be fulfilled through fulfilling of the current subobjectives:

Recognizing university students' preparations concerning using digital platform "Microsoft Teams".

Recognizing university students' trends concerning using digital platform "Microsoft Teams".

Recognizing the aspects of university students' benefits from digital platform "Microsoft Teams".

Recognizing the obstacles hindering university students from using digital platform "Microsoft Teams" and getting benefits from it.

Recommending suggestions to help students to overcome the obstacles of using digital platform "Microsoft Teams" and getting benefits from this educational platform.

\section{Fourthly: The Importance of the Study:}

Spreading digital education culture and the benefits of using digital educational platforms in university education. 
Shedding light on the obstacles hindering university students from using digital platform "Microsoft" and getting benefits from it.

Determining the obstacles of using digital platform "Microsoft teams" and getting rid of these obstacles.

Setting suggestions to help university students to confront the obstacles of using digital platform "Microsoft teams" to enrich the theoretical aspect of social work career in the field of digital education.

\section{Fifthly: The Study Concepts:}

\section{Obstacles concept:}

Concept of obstacles refers to all what negatively affects the achievement of objectives, executing tasks or practicing the program and vocational activities. Obstacles in Webster Dictionary are defined as pitfalls hindering the progress. (Webster, 1984, p 1014)

Obstacles may be considered as functionally and structurally harming problems hindering the satisfying of the needs (max siposin, 1975, $p$ 8).

some people think that obstacles can be considered as the disintegration of the pattern and disorder of its units and inability of the pattern to perform functions due to bad organization and the related internal stresses. (Robert k. merton, 1968, p 53).

Obstacles in this study the obstacles hindering university students from using the digital Platform "Microsoft Teams".

\section{Concept of digital educational platforms:}

Concept of the platform: platform is the place where groups of various beneficiaries in the light of clearly identified rules are exchanging ideas goods and services and anything else that can be exchanged between individuals, computers, or any machines working in behalf of humans. (Siemens Ingenuity for life, 2016, p4)

The platform is defined as the system that can be programming and allocating by the external developers and users and by this method it is being adapted to provide countless needs besides the flexibility that is providing creative ability and pioneering ideas that are not intended by the original developers. In the field of computer, the platform usually refers to the operating system and the term "platform" is often used to refer to any type of computer systems. (Bogost, lan, Montfort, Nick, 2009, p3).

B) The concept of digital platform 'Microsoft Teams' : can be defined as any devices or programs used to offer service in the light of the operating system and 
the programs are being organized according to some instructions of a specific processor (Meyer, Laurence, P 135).

Digital platform "Microsoft Teams can be defined as: educational sites in which students are exchanging discussions, ideas, content, roles distribution, and the tests and homework are electronically executed. (ELsayed, 2016, P1111).

Digital platform "Microsoft Teams" also can be defined as a group of interactive services through the internet that are enabling the students to access information and course content through the internet and these platforms are distinguished with the following (Ahn\&Edwin,2018, p5):

1- Content management

2- Dynamic Evaluation

3- Interaction

4- Immersion in knowledge society

Digital platform offers three related things: education without physical interaction, interactive practice, interaction in the platform (carols\& et al, 2017, p31).

Students through digital platform "Microsoft Teams" can access scientific content, schedule, diagrams, notifications, results, evaluation, and send their enquiries and responses. All uploaded data are being stored on files server that can be easily accessed from any computer file (Muhammad, et al,2020, p7).

The most important electronic platforms in universities used in applying hybrid education are as follow:

1- Microsoft Platform, Blue Cloud are being used in all governmental and private universities as being one of the key tools to apply Hybrid education system.

2- Cairo University Platform is considered the largest smart platform all over the world including the strongest smart education system in the world as being more developed from the normal systems.

\section{The importance of university digital educational platforms:}

1- Providing university students with curricula, communication and cooperation paving the way to generate new ideas and to contribute in developing advanced digital skills.

2- Getting rid of obstacles and barriers of communication and supporting social interactions among students and faculty teaching members.

3- Opening dialogue channels between students and faculty teaching members so as to offer more opportunities to creation and change.

4- Digital platforms allow students to access the content from everywhere at any time.

5- Digital platforms enable university institutions to contact wide range of the students from everywhere at any time. 
6- Costs saving, reducing needed resources, easiness of use, flexibility, and improving consistency during delivering the curricula (Conseil des technologies de information et des communications, 2013).

\section{The difference between electronic site and digital platforms:}

The platforms and electronic sites are similar in many characteristics and are different according to the service or target for which they are being established and this can be indicated in the following points (Openuped, 2015, p1):

1 - The site is a group of web pages that are linked together and being uploaded on one server and the web can be accessed through the browser or through special network called (local or internal Area Network) and there are two types of sites: Fixed sites and dynamic sites.

2- The platform is a dynamic frame of applications providing data in an easy way to make development process done in a fast way as well as it is considered electronic ground including many applications and interactive links.

3- In the site the interaction is done indirectly such as (seller and purchaser, Teacher and the student, trainer and the trainee) while the platform provides instant interaction between the two parties (the student, the lecturer) and between a group of individuals at the same time and this property is not available at the normal electronic sites.

4- Electronic sites try to attract visitors while users are searching for platform according to services offered to users by these platforms.

\section{Benefits of digital educational platforms:}

Benefits of university digital platforms represent in the following (Sejzi, Abbas Abdoli; Aris, baharuddin,2013, pp217:218)

1- Overcoming time and place obstacles as all you need as all you need to attend these lectures to have a computer and internet line and sitting in your room listening to the information, course, and lecture at your favorite site or the lecturer that attracts your attention.

2- Comfortably Listening to lectures as the learner has the right to choose time of attending educational session and watching videos without commitment to attend the lecture at a specific time as well as the learner will be able to done all his works without interruption, early get out of work or even get vacations.

3- Getting access to various topics and fields: learning, training, languages, human sciences, Medicine, astronomy, chemistry, mathematics, and all sciences can be accessed through open educational platforms consequently increase scientific knowledge, culture and experience through the offered training and educational courses.

4- Variation in methods of presentation as the scientific content on these platforms is being offered in various forms such as: lectures, discussions sessions, visual 
communication symposiums, and videos, thus every participant can choose the appropriate method.

5- Language improving: It improves learner or student's informal language as it is known that the best method to improve and develop the language is to listen to short videos and writing phrases in the context of speech consequently it helps to understand the lecturer and enrich linguistic vocabulary and makes the ear familiar to understand different languages.

6- Trust in resource: the internet is full of baseless and unfounded information so differentiating between correct and incorrect information so as to ensure the correctness of information as being submitted by experienced professors and experts.

\section{concept of university students:}

The word "youth" is derived from the root verb "grow up" as the period of youth is the period of strength and modernity (Arabic language Academy, 2005, p333).

Social science dictionary defines the term youth as the category of people aged between 18- 24 who finished public study as this stage witnesses the transition stage into maternity and masculinity as individuals overstep the stage of orientation and care and they become more liberated as these stage needs special care(badawy,1986,p452).

University students in this study are the students of Assuit university colleges of youth stage that are characterized by specific features.

\section{The concept of university students in this study can be identified as follows:}

The category aged between (19-25) years.

Males and females.

The students must belong to the university.

Students must be enrolled to the faculties of the university.

\section{Sixthly: Methodological procedures of the study:}

\section{Type of Study:}

this study is considered one of the analytical descriptive studies targeting identifying the characteristics of specific phenomenon through collecting and analyzing all data and concluding and generalizing the results. The current study aims at recognizing the obstacles confronting university students during their use of digital platform "Microsoft" through collecting and analyzing information then concluding results consequently setting suggestions to overcome these obstacles.

\section{Method of the study:}


The study used social survey approach through sample method as this approach is the most suitable for descriptive studies and it concentrates on current time and tackles available things.

\section{Study tools:}

A- The study depends on special manual questionnaire for university students, and the researchers put in their consideration that the data are suitable to study's problem, objectives, enquiries, and theoretical frame.

B- Content validity of the study was examined by ten arbitrators of social work professors in the universities of Helwan, Bani Sweif, and Assuit.

C- Content reliability of the study was calculated by re-test method on a sample of university students after 15 days, and reliability variable Pearson $=(0.89)$.

Fields of the study:

\section{A- The Spatial field:}

Assuit University, 18 colleges of Assuit university (7theoritcal colleges and 11 practical colleges).

\section{B- The Human field:}

Intentional stratified sample of 300 students of Assuit University.

\section{C- The Time field:}

Data are being collected during the period from 2/11/2020 to 20/12/2020.

Seventy: The study Results:

Description of study sample (University students)

Table (1) sample characteristics (University students) $S=300$

\begin{tabular}{|l|l|l|l|l|}
\hline S & Gender & Frequency & Percentage & Ranking \\
\hline A & Male & 112 & $37 \%$ & 2 \\
\hline B & Female & 188 & $63 \%$ & 1 \\
\hline & Total & 300 & $100 \%$ & \\
\hline S & Age & Frequency & Percentage & Ranking \\
\hline A & Less than 20 years & 60 & $20 \%$ & 3 \\
\hline B & From 20 to less than 22 & 50 & $16.7 \%$ & 4 \\
\hline C & From 22 to less than 24 & 100 & $33.3 \%$ & 1 \\
\hline D & From 24 and more & 90 & $30 \%$ & 2 \\
\hline & Total & 300 & $100 \%$ & \\
\hline S & Faculty & Frequency & Percentage & Ranking \\
\hline A & Practical & 170 & $56.7 \%$ & 1 \\
\hline B & Theory & 130 & $43.3 \%$ & 2 \\
\hline & Total & 300 & $100 \%$ & \\
\hline S & Year & Frequency & Percentage & Ranking \\
\hline A & First & 98 & $32.7 \%$ & 1 \\
\hline B & Second & 70 & $23.3 \%$ & 3 \\
\hline C & Third & 50 & $16.7 \%$ & 4 \\
\hline D & Fourth & 82 & $27.3 \%$ & 2 \\
\hline & Total & 300 & $100 \%$ & \\
\hline
\end{tabular}


The date of the table pointed out the characteristics of study sample as female's rate got the first rank with a percentage of $(63 \%)$ while male's rate got the second rate with a percentage of $(37 \%)$. Age from 22 to less than 24 got the first rank with a percentage of $(33.3 \%)$, age of 24 and more got the second rank with a percentage of (30\%), age of less than 20 years got the third rank with a percentage of $(20 \%)$, and age (from 20 to less than 22years) got the last rank with a percentage of $(16.7 \%)$. The table also indicated that the practical colleges of the sample got the first rank with a percentage of $(56.7 \%)$ while the theoretical colleges got the second rank with a percentage of (43.3\%) as the students of first year got the first rank with a percentage of (32.7\%),the students of fourth year got the second rank with a percentage of $(27.3 \%)$, the students of second year got the third rank with a percentage of $(23.3 \%)$, and the students of third year got the last rank with a percentage of $(16.7 \%)$.

Table 2 characteristics of the sample (University students) $S=300$

\begin{tabular}{|l|l|l|l|l|}
\hline S & Place of Residence & Frequency & Percentage & Ranking \\
\hline A & Countryside & 208 & $69.3 \%$ & 1 \\
\hline B & Urban area & 192 & $30.7 \%$ & 2 \\
\hline & Total & 300 & $100 \%$ & \\
\hline S & Father's job & Frequency & Percentage & Ranking \\
\hline A & Governmental employee & 80 & $26.7 \%$ & 2 \\
\hline B & Private sector employee & 35 & $11.7 \%$ & 4 \\
\hline C & Freelance works & 120 & $40 \%$ & 1 \\
\hline D & Without work & 65 & $21.6 \%$ & 3 \\
\hline & Total & 300 & $100 \%$ & \\
\hline S & Mother's job & Frequency & Percentage & Ranking \\
\hline A & Employee & 87 & $29 \%$ & 2 \\
\hline B & Without work & 213 & $71 \%$ & 1 \\
\hline & Total & 300 & $100 \%$ & \\
\hline S & No of family members & Frequency & Percentage & Ranking \\
\hline A & 3 Individuals & 28 & $9.3 \%$ & 3 \\
\hline B & 4 Individuals & 57 & $19 \%$ & 2 \\
\hline C & 5 individuals and more & 215 & $71.7 \%$ & 1 \\
\hline & Total & 300 & $100 \%$ & \\
\hline
\end{tabular}

The previous table pointed out that residence of place of study sample as countryside rate got the first rank with a percentage of $(69.3 \%)$ while rural Areas' rate got the second rate with a percentage of (30.7\%). "Father's job" as freelance works got the first rank with a percentage of (40\%), "Father's job" as governmental employee got the second rank with a percentage of $(26.7 \%)$, age of less than 20 years got the third rank with a percentage of $(20 \%)$, "Father without a job" got the third rank with a percentage of (21.6\%), and "Father's job" as private sector's employee got the fourth rank with a percentage of $(11.7 \%)$. The table also indicated that mother without a job of the study sample got the 
first rank with a percentage of (71\%) while the mother's job as an employee got the second rank with a percentage of $(29 \%)$. The number of family's member as "5 members and more" sample got the first rank with a percentage of $(71.7 \%)$, four members of family got the second rank with a percentage of $(19 \%)$, and three members of family got the last rank with a percentage of $(9.3 \%)$.

Study results concerning study enquiries:

Table 3 The range of providing Preparation for university students (University students) $S=300$

\begin{tabular}{|c|c|c|c|c|c|c|c|c|c|c|}
\hline \multirow[t]{3}{*}{$\mathrm{S}$} & \multirow{3}{*}{ 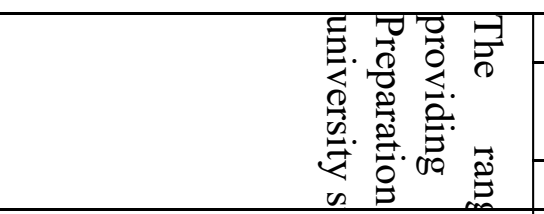 } & \multicolumn{6}{|c|}{ RESPONSES } & \multirow{3}{*}{ 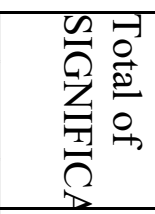 } & \multirow{3}{*}{$\begin{array}{l}3 \\
\stackrel{3}{0}\end{array}$} & \multirow{3}{*}{ 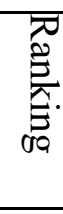 } \\
\hline & & \multicolumn{2}{|c|}{ YES } & \multicolumn{2}{|c|}{$\begin{array}{l}\text { TO SOME } \\
\text { EXTENT }\end{array}$} & \multicolumn{2}{|l|}{ NO } & & & \\
\hline & & $\mathrm{F}_{\mathrm{i}}$ & $\%$ & $\mathrm{~F}_{\mathrm{i}}$ & $\%$ & $\mathrm{~F}_{\mathrm{i}}$ & $\%$ & & & \\
\hline 1 & I have a cell phone. & 200 & $66.7 \%$ & 75 & $25 \%$ & 25 & $8.3 \%$ & 775 & 2.58 & 1 \\
\hline 2 & $\begin{array}{l}\text { I have the skill of using Mi } \\
\text { Teams }\end{array}$ & 29 & $9.7 \%$ & 71 & $23.6 \%$ & 200 & $66.7 \%$ & 429 & 1.43 & 7 \\
\hline 3 & I have a computer at home & 13 & $4.3 \%$ & 8 & $2.7 \%$ & 279 & $93 \%$ & 334 & 1.11 & 8 \\
\hline 4 & I can access internet at any time & 165 & $55 \%$ & 65 & $21.7 \%$ & 70 & $23.3 \%$ & 695 & 2.32 & 4 \\
\hline 5 & $\begin{array}{l}\text { Internet package is sufficient to } \\
\text { attend lectures online }\end{array}$ & 50 & $16.7 \%$ & 100 & $33.3 \%$ & 150 & $50 \%$ & 500 & 1.66 & 6 \\
\hline 6 & $\begin{array}{l}\text { My colleagues help me in conn } \\
\text { With Electronic platform. }\end{array}$ & 185 & $61.6 \%$ & 65 & $21.7 \%$ & 50 & $16.7 \%$ & 735 & 2.45 & 2 \\
\hline 7 & $\begin{array}{l}\text { The university helps me in } \\
\text { any } \\
\text { Problem relating to the platforn }\end{array}$ & 95 & $31.7 \%$ & 85 & $28.3 \%$ & 120 & $40 \%$ & 575 & 1.92 & 5 \\
\hline 8 & $\begin{array}{l}\text { There is a problem relating } \\
\text { email. }\end{array}$ & 199 & $66.3 \%$ & 35 & $11.7 \%$ & 66 & $22 \%$ & 733 & 2.44 & 3 \\
\hline & Total & 936 & & 504 & & 960 & & 4676 & 15.58 & \\
\hline & Mean & 117 & & 63 & & 120 & & 584.5 & 1.95 & \\
\hline
\end{tabular}

The previous table pointed out range of providing preparation among university students to enable them to use electronic platform as the phrase "I have a cell phone." got the first rank with a mean of (2.58) the phrase " My colleagues help me in connecting With Electronic platform." got the second rank with a percentage of (2.45), the phrase " There is a problem relating to my email." got the third rank with a percentage of (2.44), the phrase " I can access internet at any time." got the fourth rank with a percentage of (2.32), the phrase " The university helps me in solving any Problem relating to the platform." got the fifth rank with a percentage of (1.92), the phrase "Internet package is sufficient to attend lectures online." got the sixth rank with a percentage of (1.66), the phrase " I have the skill of using Microsoft Teams." got the seventh rank with a percentage of (1.43), the phrase "I have a computer at home." got the last rank with a percentage of (1.11), and all these results are consistent with the results of Aly's study in 2016 concerning the preparation range of community work 
students to electronic learning and the study concluded that the students had the motivation concerning electronic learning.

Table (4), university students' trends concerning using digital platform "Microsoft), $S=300$.

\begin{tabular}{|c|c|c|c|c|c|c|c|c|c|c|}
\hline \multirow[t]{3}{*}{$\mathrm{S}$} & \multirow{3}{*}{$\begin{array}{l}\text { University students' trends } \\
\text { Concerning using Electronic } \\
\text { Platform Microsoft }\end{array}$} & \multicolumn{6}{|c|}{ RESPONSES } & \multirow{3}{*}{ 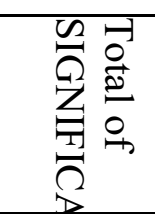 } & \multirow{3}{*}{ 赵 } & \multirow{3}{*}{ 㟒 } \\
\hline & & \multicolumn{2}{|l|}{ YES } & \multicolumn{2}{|c|}{$\begin{array}{l}\text { TO SOME } \\
\text { EXTENT }\end{array}$} & \multicolumn{2}{|l|}{$\mathrm{NO}$} & & & \\
\hline & & $\mathrm{F}_{\mathrm{i}}$ & $\%$ & $\mathrm{~F}_{\mathrm{i}}$ & $\%$ & $\mathrm{~F}_{\mathrm{i}}$ & $\%$ & & & \\
\hline 1 & $\begin{array}{l}\text { Electronic platform provides } \mathrm{m} \\
\text { Huge capabilities }\end{array}$ & 220 & $73.3 \%$ & 65 & $21.7 \%$ & 15 & $5 \%$ & 805 & 2.68 & 2 \\
\hline 2 & $\begin{array}{l}\text { The platform fad } \\
\text { communication } \\
\text { With university professor. }\end{array}$ & 235 & $78.4 \%$ & 40 & $13.3 \%$ & 25 & $8.3 \%$ & 810 & 2.70 & 1 \\
\hline 3 & I like Using Internet in learning & 198 & $66 \%$ & 32 & $10.7 \%$ & 70 & 23.30 & 728 & 2.43 & 5 \\
\hline 4 & $\begin{array}{l}\text { Traditional education in the col } \\
\text { sufficient for me }\end{array}$ & 175 & $58.3 \%$ & 45 & $15 \%$ & 80 & $26.7 \%$ & 695 & 2.32 & 7 \\
\hline 5 & $\begin{array}{l}\text { I have the intention to use digit } \\
\text { platform in education }\end{array}$ & 177 & $59 \%$ & 23 & $7.7 \%$ & 100 & $33.3 \%$ & 677 & 2.26 & 8 \\
\hline 6 & $\begin{array}{l}\text { The platform enables learning } \\
\text { time and everywhere }\end{array}$ & 200 & $66.7 \%$ & 55 & $18.3 \%$ & 45 & $15 \%$ & 755 & 2.52 & 4 \\
\hline 7 & $\begin{array}{l}\text { My field does not require } \\
\text { remote } \\
\text { Learning platform }\end{array}$ & 190 & $63.3 \%$ & 30 & $10 \%$ & 80 & $26.7 \%$ & 710 & 2.37 & 6 \\
\hline 8 & $\begin{array}{l}\text { The platform presents sc } \\
\text { content } \\
\text { In an interesting way. }\end{array}$ & 218 & $72.7 \%$ & 60 & $20 \%$ & 22 & $7.3 \%$ & 796 & 2.65 & 3 \\
\hline & Total & 1618 & & 350 & & 437 & & 5976 & 19.92 & \\
\hline & Mean & 201.1 & & 43.7 & & 54.6 & & 747 & 2.49 & \\
\hline
\end{tabular}

The previous table pointed out the trends of university students concerning using electronic platform as the phrase "The platform facilitates communication with university professor." got the first rank with a mean of (2.70), the phrase" Electronic platform provides me with Huge capabilities " got the second rank with a percentage of (2.68), the phrase " The platform presents scientific content In an interesting way." got the third rank with a percentage of (2.65), the phrase " The platform enables learning at any time and everywhere " got the fourth rank with a percentage of (2.52), ), the phrase " I like Using Internet in learning." got the fifth rank with a percentage of (2.43), My field does not require using remote Learning platform " got the sixth rank with a percentage of (2.37), the phrase " Traditional education in the college is sufficient for me" got the seventh rank with a percentage of (2.32), the phrase " I have the intention to use digital platform in education " got the last rank with a percentage of (2.26), and all these results are confirmed by Badreya study in 2015 concerning university students' trends concerning using social communication platforms in university 
education and the study concluded that many students lacked the skill of dealing with modern technology and it recommended the necessity of getting rid of technological illiteracy in modern education.

Table (5), university students' benefits from using digital platform "Microsoft), $S=300$.

\begin{tabular}{|c|c|c|c|c|c|c|c|c|c|c|}
\hline \multirow[t]{4}{*}{$\mathrm{S}$} & \multirow{3}{*}{$\begin{array}{l}\text { university students' benefits from } \\
\text { using electronic platform Microsoft }\end{array}$} & \multicolumn{6}{|c|}{ RESPONSES } & \multirow{3}{*}{ 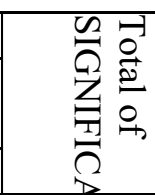 } & \multirow{3}{*}{$\begin{array}{l}3 \\
\stackrel{8}{8}\end{array}$} & \multirow{3}{*}{ 恩 } \\
\hline & & & & & & & & & & \\
\hline & & \multicolumn{2}{|l|}{ YES } & \multicolumn{2}{|c|}{$\begin{array}{l}\text { TO SOME } \\
\text { EXTENT }\end{array}$} & \multicolumn{2}{|l|}{ NO } & & & \\
\hline & & $F_{i}$ & $\%$ & $\mathrm{~F}_{\mathrm{i}}$ & $\%$ & $\mathrm{~F}_{\mathrm{i}}$ & $\%$ & & & \\
\hline 1 & Chatting with university professor & 200 & $66.7 \%$ & 45 & $15 \%$ & 55 & $18.3 \%$ & 745 & 2.48 & 3 \\
\hline 2 & Getting courses scientific content & 210 & $70 \%$ & 60 & $20 \%$ & 30 & $10 \%$ & 780 & 2.60 & 2 \\
\hline 3 & Chatting with colleagues. & 260 & $86.7 \%$ & 10 & $3.3 \%$ & 30 & $10 \%$ & 780 & 2.60 & 1 \\
\hline 4 & Writing down and exchanging notes. & 150 & $50 \%$ & 75 & $25 \%$ & 75 & $25 \%$ & 675 & 2.25 & 4 \\
\hline 5 & Online Exam & 45 & $15 \%$ & 30 & $10 \%$ & 225 & $75 \%$ & 420 & 1.40 & 7 \\
\hline 6 & Getting access to lectures at any time & 130 & $43.3 \%$ & 100 & $33.3 \%$ & 70 & $23.3 \%$ & 660 & 2.20 & 5 \\
\hline 7 & $\begin{array}{l}\text { Acquiring skill in using Microsoft tean } \\
\text { Program }\end{array}$ & 110 & $36.7 \%$ & 80 & $26.7 \%$ & 110 & $36.6 \%$ & 600 & 2.00 & 6 \\
\hline & Total & 1101 & & 400 & & 595 & & 4710 & 15.7 & \\
\hline & Mean & 157.8 & & 57.1 & & 85 & & 672.8 & 2.24 & \\
\hline
\end{tabular}

The previous table pointed out university students' benefits from using electronic platform as the phrase "Chatting with colleagues." got the first rank with a mean of (2.77), the phrase" Getting courses scientific content" got the second rank with a percentage of (2.60), the phrase " Chatting with university professor " got the third rank with a percentage of (2.48), the phrase " Writing down and exchanging notes." got the fourth rank with a percentage of (2.25), the phrase " Getting access to lectures at any time" got the fifth rank with a percentage of (2.20), Online Exam " got the sixth rank with a percentage of (2.37), the phrase " Acquiring skill in using Microsoft teams program " got the last rank with a percentage of (2.00).

Table (6), obstacles hindering university students from using digital platform "Microsoft), $S=300$.

\begin{tabular}{|c|c|c|c|c|c|c|c|c|c|c|}
\hline \multirow[t]{3}{*}{$\mathrm{S}$} & \multirow{3}{*}{$\begin{array}{l}\text { Obstacles hindering } \\
\text { University students from using } \\
\text { Electronic Platform }\end{array}$} & \multicolumn{6}{|c|}{ RESPONSES } & \multirow{3}{*}{ 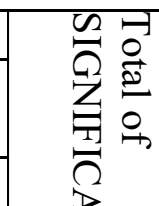 } & \multirow{3}{*}{ 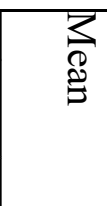 } & \multirow{3}{*}{ 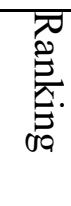 } \\
\hline & & \multicolumn{2}{|c|}{ YES } & \multicolumn{2}{|c|}{$\begin{array}{l}\text { TO SOME } \\
\text { EXTENT }\end{array}$} & \multicolumn{2}{|l|}{$\mathrm{NO}$} & & & \\
\hline & & $\mathrm{F}_{\mathrm{i}}$ & $\%$ & $\mathrm{~F}_{\mathrm{i}}$ & $\%$ & $\mathrm{~F}_{\mathrm{i}}$ & $\%$ & & & \\
\hline 1 & Poor infrastructure of Internet. & 258 & $86 \%$ & 22 & $7.3 \%$ & 20 & $6.7 \%$ & 838 & 2.79 & 2 \\
\hline 2 & $\begin{array}{l}\text { Lack of sufficient training to us } \\
\text { electronic platform }\end{array}$ & 240 & $80 \%$ & 30 & $10 \%$ & 30 & $10 \%$ & 810 & 2.70 & 4 \\
\hline 3 & $\begin{array}{l}\text { Inability to control the lecture } \\
\text { the } \\
\text { Large number of students. }\end{array}$ & 160 & $53.3 \%$ & 20 & $6.7 \%$ & 120 & $40 \%$ & 640 & 2.13 & 13 \\
\hline 4 & $\begin{array}{l}\text { It wastes time without achievin } \\
\text { Benefits of education }\end{array}$ & 140 & $46.7 \%$ & 20 & $6.7 \%$ & 140 & $46.7 \%$ & 600 & 1.50 & 15 \\
\hline 5 & Repeated breakdowns of Intern & 230 & $76.7 \%$ & 60 & $20 \%$ & 10 & $3.3 \%$ & 820 & 2.73 & 3 \\
\hline
\end{tabular}




\begin{tabular}{|l|l|l|l|l|l|l|l|l|l|l|}
\hline 6 & $\begin{array}{l}\text { Lack of required financial res } 270 \\
\text { to } \\
\text { Use the platform }\end{array}$ & $90 \%$ & 10 & $3.3 \%$ & 20 & $6.7 \%$ & 850 & 2.83 & 1 \\
\hline 7 & $\begin{array}{l}\text { Mastering English language } \\
\text { the } \\
\text { Platform }\end{array}$ & 199 & $66.3 \%$ & 40 & $13.3 \%$ & 61 & $20.4 \%$ & 738 & 2.46 & 10 \\
\hline 8 & $\begin{array}{l}\text { Lack of university professors' s } \\
\text { Managing online lecture. }\end{array}$ & 185 & $61.7 \%$ & 60 & $20 \%$ & 55 & $18.3 \%$ & 730 & 2.43 & 11 \\
\hline 9 & $\begin{array}{l}\text { Invalidity of electronic platf } \\
\text { tests }\end{array}$ & $62.7 \%$ & 75 & $25 \%$ & 37 & $12.3 \%$ & 751 & 2.51 & 8 \\
\hline 10 & $\begin{array}{l}\text { Lack of required equipment to } \\
\text { Platform }\end{array}$ & 200 & $66.7 \%$ & 50 & $16.7 \%$ & 50 & $16.7 \%$ & 750 & 2.50 & 9 \\
\hline 11 & $\begin{array}{l}\text { Lack of university prof } \\
\text { motivation } \\
\text { To use the platform }\end{array}$ & $48.3 \%$ & 65 & $21.7 \%$ & 90 & $30 \%$ & 655 & 2.18 & 12 \\
\hline 12 & $\begin{array}{l}\text { Repeated breakdowns of m } \\
\text { phone }\end{array}$ & 205 & $68.3 \%$ & 45 & $15 \%$ & 50 & $16.7 \%$ & 755 & 2.52 & 7 \\
\hline 13 & $\begin{array}{l}\text { Courses nature does not suit pla } \\
\text { Using }\end{array}$ & $46.7 \%$ & 35 & $11.7 \%$ & 125 & $41.6 \%$ & 615 & 2.05 & 14 \\
\hline 14 & Lack of incentive to use the pla & 204 & $68 \%$ & 55 & $18.3 \%$ & 41 & $13.7 \%$ & 763 & 2.54 & 6 \\
\hline 15 & $\begin{array}{l}\text { Shortage of awareness among s } 210 \\
\text { Members concerning this type } \\
\text { education through digital platfo }\end{array}$ & $70 \%$ & 30 & $10 \%$ & 60 & $20 \%$ & 750 & 2.50 & $(9)$ \\
\hline 16 & $\begin{array}{l}\text { Lack of practical training to us } \\
\text { electronic platform }\end{array}$ & 240 & $80 \%$ & 25 & $8.3 \%$ & 35 & $11.7 \%$ & 805 & 2.68 & 5 \\
\hline & Total & 3214 & & 642 & & 944 & & 11870 & 39.56 & \\
\hline & Mean & 200.8 & & 40.1 & & 59 & & 741.8 & 2.47 & \\
\hline
\end{tabular}

The previous table pointed out the obstacles hindering university students from using electronic platform as the phrase "Lack of required financial resources to Use the platform." got the first rank with a mean of (2.83), the phrase" Poor infrastructure of Internet." got the second rank with a percentage of (2.79), the phrase " Repeated breakdowns of Internet" got the third rank with a percentage of (2.73), the phrase " Lack of sufficient training to use electronic platform." got the fourth rank with a percentage of (2.70), the phrase " Lack of practical training to use electronic platform " got the fifth rank with a percentage of (2.68), Lack of incentive to use the platform " got the sixth rank with a percentage of (2.54), the phrase " Repeated breakdowns of my cell phone " got the seventh rank with a percentage of (2.52), the phrase " Invalidity of electronic platform in tests " got the eights rank with a percentage of (2.51), the phrases " Shortage of awareness among society Members concerning this type of education through digital platform " and " Lack of required equipment to use the platform " got the ninth rank with a percentage of (2.50), the phrase " Mastering English language to use the Platform " got the tenth rank with a percentage of (2.46), the phrase " Lack of university professors' skills in Managing online 
lecture." got the eleventh rank with a percentage of (2.43), the phrase " Lack of university professors' motivation To use the platform " got the twelfth rank with a percentage of (2.18), the phrase " It wastes time without achieving Benefits of education " got the last rank with a percentage of (1.50), and this results are consistent with study of Slaeh in 2014 concerning the obstacles hindering social work students from using electronic educational applications and the study mentioned the following obstacles: shortage of self-abilities of students and other criteria related to university such as time stresses, inability to login into the Internet, and the weakness of communication network.

Table (7), Suggestions of university students to activate using digital platform "Microsoft), $S=300$.

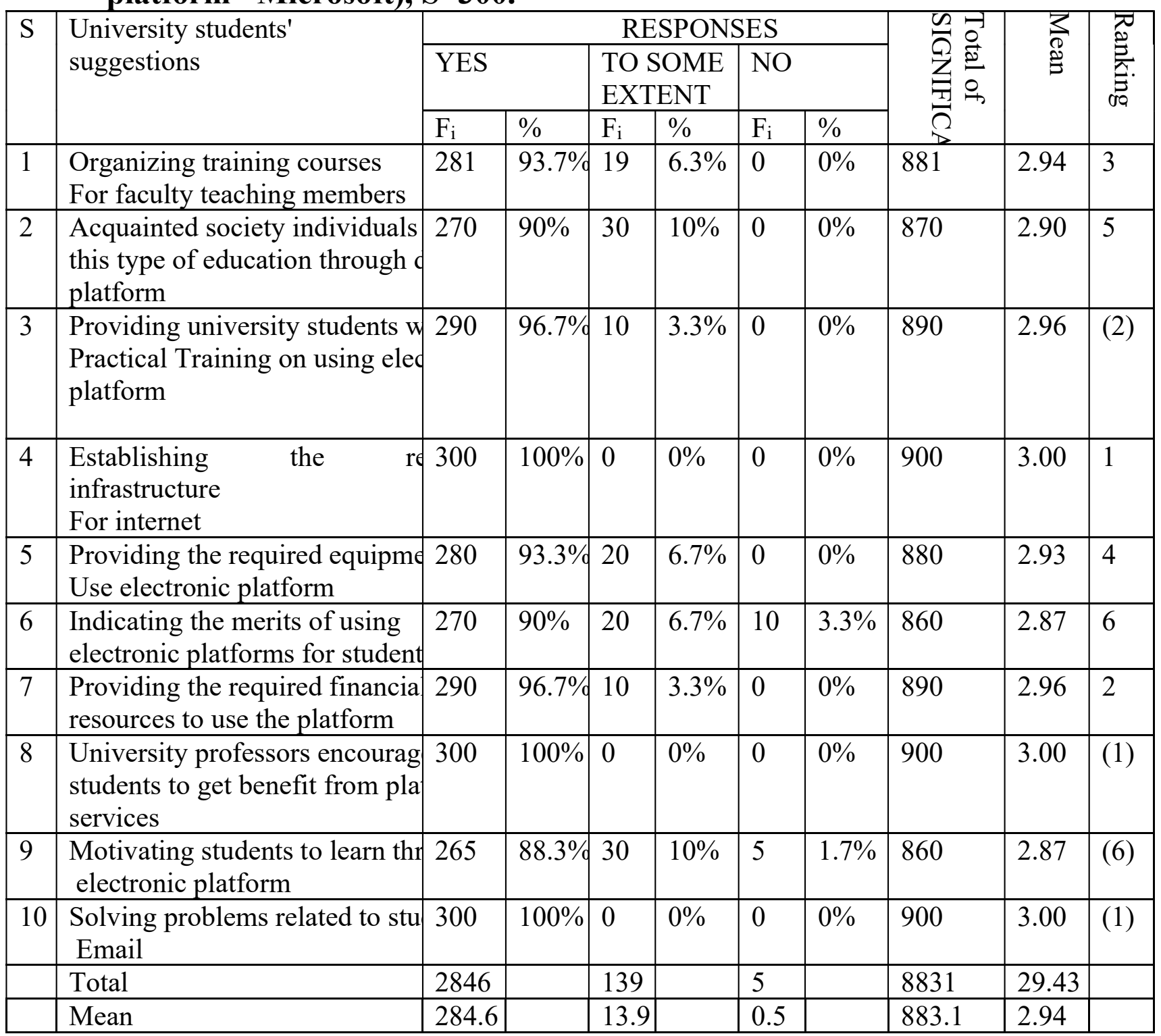

The previous table pointed out the suggestions of university students to activate using electronic platform as the phrases "Establishing the required infrastructure 
for internet, University professors encourage students to get benefit from platform services, solving problems related to students' email." got the first rank with a mean of (3.00), the phrases" Providing the required financial resources to use the platform, and Providing university students with a Practical Training on using electronic platform." got the second rank with a percentage of (2.96), the phrase " Organizing training courses For faculty teaching members " got the third rank with a percentage of (2.94), the phrase " Providing the required equipments to Use electronic platform " got the fourth rank with a percentage of (2.93), the phrase " Acquainted society individuals with this type of education through digital platform " got the fifth rank with a percentage of (2.90), the phrases" Motivating students to learn through electronic platform, and Indicating the merits of using electronic platforms for students." got the last rank with a percentage of (2.87).

\section{Discussion:}

Although the merits of using digital platform "Microsoft teams ", there are many obstacles confronting university students while using digital platform "Microsoft Teams" and these obstacles are as follows:

The platform needs infrastructure such as computers and high speed of Internet.

Lack of students' motivation toward digital learning as a result of spending a lot of time browsing electronic sites.

Difficulty of evaluation and development of criteria.

Reducing innovation and creation level in answers of the exams.

It needs specialized experts to manage digital educational systems as this system needs qualified cadre to execute and apply and manage this technical system

Inability of many current teachers to use digital technology.

\section{Recommendations:}

Establishing a well-built infrastructure so as to guarantee the proper use of electronic platform "Microsoft Teams".

The university should provide students with continuous training courses on the appropriate use of platform.

Encouraging and obliging professors of social work to electronically upload all their academic courses so as to encourage the students to get benefits from the advantages of digital platform "Microsoft Teams". 
The university and professors should apply mechanisms to encourage unwilling students to use digital platform via getting rid of all moral and financial obstacles hindering them from the use of digital platform. 


\section{References}

Abou Kheris,Hany Gouda(2020): requirements of using digital platforms in Egypt as recognized by teaching members and students, applied study on Fayoum university, published research in the magazine of faculty of social work for social research and studies, Fayoum University. (IN Arabic Language).

Ahmed,Ismaeil Osman(2020): challenges of digital education Arab region, founding vision, published research in Arab Institution for Education, Science and Arts, April, No 12. (IN Arabic Language).

Ahn,J.\& Edwin,A. (2018).An e-Learning Model for Teaching Mathematics on an Open Source Learning Platform, Journal of International Review of Research in Open and Distributed Learning, 19 ALGamaan, Safaa, ALGamaan, Sanaa (2019): obstacles of digital education among special education teachers, published research in Arab journal for disability sciences and talent, Arab Institution for Education, Science and Arts, anuary, No 6. (IN Arabic Language).

ALSobeihy, Afnan Hemed, sleem, ranya youssef(2020)the effectiveness of teaching methods through digital platforms in developing academic achievement among the students of faculty of education for girls in Jeddah, published research in Arab Journal for educational and psychological studies, Association of Arab educators ,July, No(123). (IN Arabic Language).

Aly, Hayam Aly (2016): Readiness of community work students to electronic education, published research in social work magazine, Egyptian Association for social workers, January, Issue 55. (IN Arabic Language).

Arabic Language Academy (2005): concise dictionary, Cairo, Governmental publishers. (IN Arabic Language).

Badawy, Ahmed Zaki (1986): social science dictionary, Beirut, Lebanon library. (IN Arabic Language).

Badreya, A, 2015, Digital Media Platforms and Education: The Uses of Social Networking in the UAE and China, Journal of Media Critiques [JMC] - Vol.1 No.1 June. (IN Arabic Language).

Bogost, Ian;Montfort, Nick. Platform Studies: Frequently Questioned Answers. Page 3. available at :http://bogost.com/downloads/bogost_montfort_dac_2009.pdf.

Carols, D, \& et al, 2017, Digital Education in the Classroom, IEEE Global Engineering Education Conference (EDUCON), 25-28 April, Athens, Greece Conseil des technologies de l'information et des communications. Étude du sous-secteur des plateformes numériques : Une analyse de la situation. 
Disponible sur le site :http://www.ictc-ctic.ca/wpcontent/uploads/2013/05/ICTC_Digital_Platforms_Report_FR.pdf Darwish, Ahmed Ael(2020) ): Electronic games in the age of digital platforms,cairo,Dar ELOlum publishing center. (IN Arabic Language).

Deyab, Zahia,Berweis, Warda (2019): obstacles of electronic education in Algerian school, published research in Arab Institution for Education, Science, and Arts, February, No7. (IN Arabic Language).

ELHamidawy, Yaser Khodeir (2020): digital communication platforms and green technology, contemporary applied vision in education, Cairo, E1Sahab for publishing. (IN Arabic Language).

ELMizr, Hemd bent Oqueil(2014): female students' trends concerning using Electronic platform in teaching social work, published research in the jounal of faculty of Arts, King Souad University, May, vol26, No 2. (IN Arabic Language).

ELMosei, Abdellah, ELMoubarak, Ahmed (2005): principles and applications of digital education, ver1, data network institution, Riyadh. (IN Arabic Language).

ELRabghy, monira Mohamed (2019) using open source electronic courses in vocational development for science female teachers in Jeddah, published research in science journal for education and psychology, National research center in Ghaza, may, vol3, No 10. (IN Arabic Language).

ELsayed, Abdel aal Abdallah (2016): Electronic educational platforms "Emodo" future vision for social electronic learning environments, electronic educational magazine, Mansoura University. (IN Arabic Language).

Emmanuel, R \& et al, 2018, Intergeo: a Digital Platform for University Education on Geomorphological Heritage, The European Association for

.Conservation of the Geological Heritage, April(IN Arabic Language).

Ismaeil, Zaynab Mohamed(2019): the impact of interaction between adjusting method and the type of feedback through digital platforms in developing the effectiveness of vocational decision taking among graduate studies students, published research in educational journal, faculty of Education, AL Azhar University, January, No 181, Part3. (IN Arabic Language).

Kazber, Amal Kazber (2020): role of digital education in confronting pandemic covid 19, forum entitled "contemporary education between indoctrination experiences and education effectiveness in Algerian University of kasdi Merbah, ouargla ,Algeria. (IN Arabic Language).

Khayaia, Yaser Mohamed (2019): role of digital platforms in supporting and developing sciences for middle stage students, published research in Arab educational magazine, Arab Institution for Education, Science and Arts, February, No 7. (IN Arabic Language). 
Max siposin, 1975, introduction to social work practice, macmillan co. inc,new york

Mohamed, Basem Ibn Naief(2020): determining university students trends concerning using digital platforms in university education in Kingdom of Saudi Arabia, Taibah University as a model, published research in Taibah University for arts and human sciences, No 22. (IN Arabic Language).

Mohamed, Hanaa Aref (2012): a suggested program to activate electronic education mechanisms in university field from the prospective of community work, published research in the $25^{\text {th }}$ international scientific conference, Helwan University, March Part 1. (IN Arabic Language).

Mohamed, Karim rafat(2020)impact of using interactive educational platforms in improving some teaching skills of the student and the teacher at faculty of physical Education Benha university. Unpublished $\mathrm{PhD}$ thesis, Benha University, faculty of Physical Education, Methodology Department. (IN Arabic Language).

Mohamed, Shaimaa Rabiea(2019): using electronic educational platform "schoology" in developing the skills of digital education units among students of education technology, unpublished master thesis, Fayoum University, faculty of education, Methodology Department. (IN Arabic Language).

Muhammad, N \& et al, 2020, Transforming universities in interactive digital platform: case of city university of science and information technology, Education and Information Technologies, July, Springer Science (IN Arabic Language).

Oleg Ye. \& et al, 2018, digital transformation of university education in Ukraine: trajectories of development in the conditions of new technological and economical order, Information Technologies and Learning Tools, Vol 64, №2

OpenupED. Definition Massive Open Online Courses (MOOCs). Creative Common.Version 1.1, 2015. P. 1.

Robert k. merton, 1968, social theory and social structure, the free press, new York.

Saleh, Emad Farouq,(2014): obstacles hindering social work students from using electronic educational applications (Model), published research in the journal of social work, Egyptian Association for social workers, January, No 51. (IN Arabic Language).

Salem, Ahmed Mohamed (2004): Digital education and educational Technology, Ver1, faculty of Education, Zagazig university, ELRashed library. (IN Arabic Language).

Sejzi, Abbas Abdoli; Aris, Baharuddin.Learning Management System (LMS) and Learning Content Management System (LCMS) at Virtual University.2nd 
International Seminar on Quality and Affordable Education. 2013.P. 217،218. (IN Arabic Language).

SIEMENS ingennity for life. The role of platforms for digitalisation of European industry. P. 4. Available at :https://ec.europa.eu/futurium/en/system/files/ged/2016_12_07_digitalplatforms _siemens_position.pdf

Sousa, A. Rocha, M, 2018, digital learning in an open education platform for higher education students, Proceedings of EDULEARN18 Conference, 2nd-4th July, Palma, Mallorca, Spain

Vojtech, R, \& Milan, R, 2016, Accessibility of Digital Platforms at Universities for Students with Visual Impairment and Blindness, Information Technologies and Learning Tools. Webster, new world dictionary, 1984, the American languges Cleveland and new York..

Zaytoun, Hasan Hussein(2001): Designing teaching in the light of organizational vision, Alam ELKoteb, cairo. (IN Arabic Language). 
مجلة كلية الخدمة الاجتماعية للدر اسات و البحوث الاجتماعية - جامعة الفيوك 